\title{
The Imperative of the Corporation and Socially Conscious Leadership
}

\author{
Ekpen Owie \\ Walden University
}

\begin{abstract}
The word corporation and the activities of corporations around the world are no longer a mystery to many. Laws create corporations as persons, independent of the owners. There have been widespread debates about the propensity of corporations to harm others while trying to maximize profits, as well as the arguments that corporations should not delve into corporate social responsibility unless it directly enhances the bottom line. Nevertheless, individuals run corporations. I posit from a synthesis of literature that such individuals, if socially conscious, could institute the right governance mechanisms for driving corporate social responsibility and balancing multistakeholder interests.
\end{abstract}

Keywords: the corporation, corporate social responsibility, stakeholder, socially conscious leadership

\section{Introduction}

Leaders play significant roles in the success of corporations. According to Yammarino (2013), effective leadership helps corporations achieve set targets. Leaders propel the leadership process (Owie, 2017a). In the same vein, good leaders enrich the financial and psychological states of shareholders as well as ensuring the corporation thrives and prospers (Hogan, Curphy, \& Hogan, 1994; Hogan \& Kaiser, 2005). Conversely, an ineffective leader does the opposite for stakeholders and the corporation as a whole. As Kaiser, LeBreton, and Hogan (2015) put it, ineffective leaders will fail to enhance and empower stakeholders as well as fail to provide vision and flexibility for the corporation as a whole.

Socially conscious leadership, on the hand, goes beyond the interests of shareholders and the corporation. According to Peterson and Patel (2016), socially conscious leadership provides the platform for bridging the gap between the traditional (shareholder goals) and contemporary (shareholder and social goals) business practices. Socially conscious leadership is akin to moral management that involves profit maximization in line with legal and ethical considerations (Carroll, 1991). Thus, socially conscious leaders pursue agendas that include not just issues related to the maximization of the corporation's profitability but the needs of society, the environment, and other stakeholders, such as the employees or suppliers.

\section{The Corporation}

Leaders manage corporations that the law regards as independent entities. The corporation is defined as "a body formed and authorized by law to act as a single person although constituted by one or more persons and legally endowed with various rights and duties including the capacity of succession" ("Corporation," n.d., para. 2). Similarly, the corporation is a system that consists of primary stakeholders that create and distributes wealth for its survival (Clarkson, 1995).

Please address queries to: Ekpen Owie, Walden University. Email: ekpen.owie@waldenu.edu 
According to Bakan (2004), "the corporation's legally defined mandate is to pursue, relentlessly and without exception, its own self-interest, regardless of the harmful consequences it might cause to others" (Bakan, 2004, p. 1). In addition, the corporation as a legal institution dictates the activities of those that operate under its auspices using inherent unique structures and imperatives (Bakan, 2004). In light of this, how does the socially conscious leader act in the midst of the legality of the corporation as described? In this article, I present, analyze, and synthesize relevant literature, arriving at the conclusion that the corporate social responsibility (CSR) framework provides socially conscious leaders the platform needed to drive contemporary business practices that take into consideration the interest of all stakeholders.

Corporations by law have the mandate to generate as much profit as possible for shareholders (Kelly, 2003). They control the lives of people and the society as well as their regulators in government and have always been fraught with corruption and fraud (Bakan, 2004). The corporation is a legal institution with the mandate and capacity to operate according to the law (Bakan, 2004). Bakan (2004) argued that the legal mandate of corporations and their enormous wealth allow them to control people and the society. Thus, it is essential to understand the imperatives of corporations in order to make changes in the interest of the society.

The enactment of the corporation as an individual, separate from its owners or investors was in the nineteenth century era (Bakan, 2004). The peculiar design of the corporation that delineates ownership from management has engendered fraud and scandal over the years (Bakan, 2004). This delineation underscores the limited liability aspect of corporations, which critics and supporters have argued over. As Bakan (2004) pointed out, the separation, for critics, implies that owners become morally passive and avoid any sense of responsibility towards unfair actions of the firm. In the same vein, Clarkson (1995) posited that such a divide could also lead to the insufficient distribution of wealth for the owners as well. That is, leaders and managers focus on their pay irrespective of how the firm performs to the detriment of shareholders.

Hence, in this present time, corporate scandals endure where agents act against the interest of owners. Bakan (2004) pointed out that the loss of powers by stockholders due to the size of the investment pool and legal separation has meant managers had more control over the corporation and acted in their own selfish interests. This situation has driven the notion of corporate governance in corporations, which according to Crişan-Mitra (2015) started in the nineteenth century to facilitate contracts implementation and to protect property rights and collective action" (p. 467). On the other hand, Kelly (2003) argued that corporate governance structures negatively influence the natural law of the market where people ought to own what they directly generated. Thus, for Kelly (2003), the ownership ideal or property right as it were, is the problem of the corporation.

The legal framework that births the corporation is devoid of any clause that prevents the corporation from doing anything that will result in harm to others in the course of maximizing profits (Bakan, 2004). As such, the inability of corporations to have any iota of morality makes them psychopaths (Bakan, 2004). Similarly, because corporations are considered as individuals and act in immoral ways, many scholars have argued that they can be regarded as psychopaths (Stibbe, 2013; Wexler, 2008).

On the other hand, some believe that individuals who are psychopathic make a corporation psychopathological, even though corporations are regarded as individual entities in the law. Personality traits influence how leaders act within the corporation (Boddy, 2010; Klann, 2003). Consequently, corporations are a reflection of the individuals that manage them. Notwithstanding, 
the corporation has remained true to its flawed character of profiteering and its character construed as psychopathic despite attempts to paint a different picture through its CSR policies (Bakan, 2004).

\section{Corporate Capitalism}

The era of corporate capitalism began in the United States in the 19th century when states began to modify their laws on a competitive basis to attract investment by corporations into their states (Bakan, 2004). These modifications of laws meant corporations had fewer restrictions to expand and become the powerful and influential institution they are today (Bakan, 2004). The notion of capitalism underscores the free market ideal where one privately owns and controls capital in a socioeconomic system (Narveson, 2014).

According to McNally (2013), the free market model of the United States is the "dominant force in the post-communist world order, setting the agenda for economic governance and development" ( $p$. 1). Corporate capitalism in America "emphasizes, among other things, the pursuit of self-interest, competition, market exchange, consumerism, and using a profit/loss criterion to make decisions in organizations" (George, 2013, p. 5). Thus, it is about the maximization of returns accruable to ownership of investment.

According to Kelly (2003), due to the partially true notion that stockholders fund corporations, they make the most wealth created. This notion is the bane of corporate capitalism where in the grand scheme of the natural market law only a certain set of people make the majority of what others contributed towards. Ademola (2017) echoed a similar sentiment that this capitalist system fosters a situation where those who make the most treat others as assets in the corporation. Thus, Kelly (2003) argued that a transformation into a more democratic system is appropriate in contrast to this form of aristocratic capitalism where just one group gets the most benefit from economic gains at the detriment of employees and the community that contribute intellectual and natural resources, respectively.

\section{Socially Conscious Leader}

The socially conscious leader should bear moral responsibilities for the actions of the corporation he or she leads. Being socially responsible involves responsibility, accountability, and transparency of business operations towards, shareholders, the society, and the consideration of the environment (Karp, 2003). Thus, a socially conscious leader that is responsible does not focus on financial performance alone but makes intuitive and genuine socially responsible activities based on personal values and morals (Waldman \& Siegel, 2008).

Although most managers of corporations are morally inclined (Bakan, 2004), there are also psychopaths that run some of them. According to Bakan (2004), corporate executives owe a duty to their firms to act in their best interest and maximize profits. Therefore, how do moral leaders operate in such environments of balancing the imperatives of the corporation and the society and environment? Given the reality of what the corporation is and the market dynamics, a pragmatic approach might be the solution. Thus, leaders and managers need to be proactive while strategizing about how they can tie profitability into CSR activities.

Although globalization has strengthened the corporations' hold on the government and society, they are still at risk from citizens whose lack of trust toward them could have bottom-line consequences (Bakan, 2004). As a result, corporations are embracing CSR to boost their image and alter public perceptions in a positive way towards them (Bakan, 2004). For example, Fortune 500 companies like 
Google, BMW, and Microsoft top the charts for CSR reputation (Strauss, 2016). Google, for instance, has been recognized for its carbon neutrality, green initiatives, and workplace diversity efforts (Miceli, 2015). Similarly, Microsoft has invested resources into sustainable energy goals, environmental and ethical practices, as well as philanthropic activities (Hauser, 2016). Such steps by corporations to assuage the concerns of stakeholders and their inherent proclivity for irresponsibility run very deep.

\section{Corporate Social Responsibility}

CSR addresses concerns about the corporations' power and unaccountability that causes harm to people and the environment. CSR, as defined by the World Business Council for Sustainable Development (1998), is "the continuing commitment by business to behave ethically and contribute to economic development while improving the quality of life of the workforce and their families as well as of the local community and society at large" (p. 3). CSR is about meshing the interest of business and the society (Moir, 2001).

The 20th century witnessed the ascendance of CSR as corporations were responding to the negative perceptions of consumers who were increasingly concerned at the irresponsibility of corporations and the influence wielded with their growing size (Bakan, 2004). Both the government and corporations use CSR to deal with social and environmental harms (Doane, 2005). That said, CSR for corporations should be about an all-inclusive business responsibility beyond the fundamental economic concerns.

According to Carroll (1979), the CSR framework includes economic (use of goods and services to make profit), legal (operation within the ambit of federal, state, or local laws), ethical (operations consistent with societal moral norms), and philanthropic (voluntary promotion of goodwill) responsibilities. Corporations are increasingly under pressure to respond to the needs of stakeholders (Reich, 1998). Thus, the fulfillment of these four components of CSR and the alignment with the realities of the business landscape should be the focus of leaders of the corporations (Carroll, 1991).

On the other hand, not everyone agrees with the ideal of corporations getting involved in CSR except it enhances profits in return. As Bakan (2004) noted, several scholars have argued in favor of the fundamental imperative that corporations are about profits for shareholders and social responsibility if any, should be to advance the bottom line. Sundaram and Inkpen (2004) argued that the profit maximization imperative should be the single objective of corporations. In essence, CSR is a violation when it undercuts profits (Bakan, 2004) since corporations are empowered by law to maximize profits for shareholders (Kelly, 2003).

Despite the challenges of shareholder profitability that have limited corporate actions on social responsibility, the notion of CSR has continued to gain prominence in the business environment (Carroll, 1991). The argument then becomes whether it is immoral for corporations to engage in CSR activities because it enhances the bottom line and vice versa. Also, is CSR pragmatism on the part of the corporation and its leaders or better still construed as a win-win for all parties because, after all, corporations are about maximizing returns for investors? 


\section{Sustainability Perspectives}

The increasing demands by various stakeholders for corporations to be socially and environmentally responsible is a prominent issue in corporate strategizing and discourse (Putrevu, McGuire, Siegel, \& Smith, 2012), which brings to bear the aspect of sustainable business practices for corporations. The voluntary actions by corporations to be socially responsible in consideration of the long-term economic advantages is on the rise as corporations are responding to the interests and pressures of investors and consumers who value and legitimize socially responsible corporations (Putrevu et al., 2012). Thus, how socially conscious leaders are able to drive sustainability principles becomes imperative.

Sustainability is about balancing the considerations of people, planet, and profit by putting aside short-term gratification for the well-being of future generations (Kuhlman \& Farrington, 2010). Similarly, the concept of sustainability captures the capacity for continued practices in terms of economic, social and environmental elements in consideration of posterity (Johnston, Everard, Santillo, \& Robert, 2007). In other words, sustainability encompasses decisions that take the focus from ephemeral gains to long-term considerations involving people, the environment, and profit.

Further, in the context of sustainability at the corporate level, sustainability involves fulfilling the desires of direct (shareholders, customers, and employees) and indirect stakeholders (environmental groups, communities, and governments) while at the same time guaranteeing the ability to satisfy future stakeholders (Dyllick \& Hockerts, 2002). Unlike CSR, corporate sustainability "focuses on value creation, environmental management, environmental friendly production systems, human capital management and so forth" (Van Marrewijk, 2003, p. 102). That is, a focus on the systems and processes that enhance the triple bottom line dynamics vis-à-vis economic, social and environmental factors.

According to Jabareen (2008), the theoretical landscape of sustainability includes concepts such as ethical paradox (the indefinite maintenance of resources on one hand and the development that depletes resources on the other), natural capital stock (modifying, enhancing, and protecting natural resources), equity (fair resource allocation among present and future competing interests), ecoform (ecological habitat designs), integrative management (economic, social, and environmental interests), utopianism (imagination of perfect balance), and political global agenda (the discourse of global sustainability).

Notwithstanding, defining and conceptualizing sustainability is insufficient in the broader scheme of balancing the triple bottom line. As Ramsey (2015) noted, planning and performing sustainability is what is most important. Thus, the need for practical, sustainable activities by corporations. Because sustainability requires an inclusive consideration of both the present and the future interests, an acknowledgment of the interdependence and interconnectedness of global systems, and fostering fairness, prudence and security (Gladwin, Kennelly, \& Krause, 1995), it is an alternative view to driving social responsibility.

Lovins, Lovins, and Hawken (2007) for instance articulated what they considered as a natural capitalism roadmap about how corporations can achieve sustainability through shifts in business processes that involves waste reduction, biological recycling, biological restoration, and solutionsbased business models. In the same vein, Kelly (2009) outlined sustainable business models vis-à-vis stakeholder-owned, mission-controlled, and public-private hybrids designs corporations could embrace. These models can help corporations align with the principles of sustainability and social responsibility by addressing social challenges while maximizing profits (Owie, 2017b). Overall, these 
systems thinking perspectives as businesses are part of a complex adaptive system (Valente, 2010), are viable and practical steps and models for driving sustainable socially responsible corporate activities.

\section{Conclusion}

Corporations have grown over the years and continue to do so driven by innovation, globalization, and information technology. The essence of what corporations are, as individual entities separate from owners and as empowered by the law, has not changed. Corporations continue to act in their interest despite some attempts to change public perceptions as more accountable based on enlightened self-interest through its CSR activities. In essence, the legal bedrock that institutionalizes the corporations becomes the subject of attention.

Because the structure of the corporation somehow controls people and the society, as some scholars have illustrated with the stories about the moral ideals of executives suppressed by the corporation's goals, it is reasonable to argue that a root-cause restructuring of the corporation needs to occur. This root-cause restructuring can involve using the same laws that create corporations to limit its actions and allow for fairness and balance (Bakan, 2004; Kelly, 2003). Nevertheless, the socially conscious and responsible leader has a role to play in maximizing profits in ways that positively impact the society and the environment.

The socially conscious leader can strive to incorporate the four elements of CSR framework as described by Carroll (1979) to strike a balance among the economic, legal, ethical, and philanthropic responsibilities of the corporation. Further, socially conscious leaders could use sustainability principles to maximize profit while minimizing harm to human and the planet. Such steps could include processes for biological recycling and restoration, as proposed by Lovins et al. (2007) as well as stakeholder-centric business models presented by Kelly (2009). Altogether, the future and prospects for sustainable corporate activities driven by socially conscious leadership is bright and limitless.

\section{References}

Ademola, E. O. (2017): Impacts of capitalism and its application: A review. Advances in Multidisciplinary and Scientific Research, 3 31-36.

Bakan, J. (2004). The corporation: The pathological pursuit of profit and power. New York, NY: Free Press.

Boddy, C. R. (2010). Corporate psychopaths and organizational type. Journal of Public Affairs, 10, 300-312. doi:10.1002/pa.365

Carroll, A. B. (1979). A three-dimensional conceptual model of corporate performance. Academy of Management Review, 4, 497-505. doi:10.5465/AMR.1979.4498296

Carroll, A. B. (1991). The pyramid of corporate social responsibility: Toward the moral management of organizational stakeholders. Business Horizons, 34, 39-48. doi:10.1016/00076813(91)90005-G

Clarkson, M. E. (1995). A stakeholder framework for analyzing and evaluating corporate social performance. Academy of Management Review, 20, 92-117. doi:10.5465/AMR.1995.9503271994

Corporation. (n.d.). In Merriam-Webster's online dictionary. Retrieved from https://www.merriamwebster.com/dictionary/corporation 
Crişan-Mitra, C. (2015). Good corporate governance: Priorities and principles. Contemporary Legal \& Economic Issues, 5, 465-483.

Doane, D. (2005). Beyond corporate social responsibility: Minnows, mammoths and markets. Futures, 37, 215-229. doi:10.1016/j.futures.2004.03.028

Dyllick, T., \& Hockerts, K. (2002). Beyond the business case for corporate sustainability. Business Strategy \& The Environment, 11, 130-141. doi:10.1002/bse.323

George, J. M. (2013, June 10). Compassion and capitalism implications for organizational studies. Journal of Management, 40, 5-15. doi:10.1177/0149206313490028

Gladwin, T. N., Kennelly, J. J., \& Krause, T. S. (1995). Shifting paradigms for sustainable development: Implications for management theory and research. Academy of Management Review, 20, 874-907. doi:10.5465/AMR.1995.9512280024

Hauser, S. (2016). Microsoft releases 2016 corporate social responsibility report. Retrieved from https://blogs.microsoft.com/blog/2016/10/18/microsoft-releases-2016-corporate-socialresponsibility-report/

Hogan, R., Curphy, G. J., \& Hogan, J. (1994). What we know about leadership: Effectiveness and personality. American Psychologist, 49, 493-504. doi:10.1037/0003-066X.49.6.493

Hogan, R., \& Kaiser, R. B. (2005). What we know about leadership. Review of General Psychology, 9, 169-180. doi:10.1037/1089-2680.9.2.169.

Jabareen, Y. (2008). A new conceptual framework for sustainable development. Environment, Development \& Sustainability, 10, 179-192. doi:10.1007/s10668-006-9058-z

Johnston, P., Everard, M., Santillo, D., \& Robert, K. (2007). Reclaiming the definition of sustainability. Environmental Science and Pollution Research, 14, 60-66. doi:10.1065/espr2007.01.375

Kaiser, R. B., LeBreton, J. M., \& Hogan, J. (2015). The dark side of personality and extreme leader behavior. Applied Psychology, 64, 55-92. doi:10.1111/apps.12024

Karp, T. (2003). Socially responsible leadership. Foresight, 5, 15-23. doi:10.1108/14636680310476230

Kelly, M. (2003). Introduction. In M. Kelly (Ed.), The divine right of capital (pp. 1-11) San Francisco, CA: Berrett-Koehler. Retrieved from http://www.corporation2020.org/corporation2020/documents/Resources/Kelly.pdf

Kelly, M. (2009). Not just for profit. Strategy+Business, 54, 1-10. Retrieved from http://www.strategy-business.com/media/file/enews-02-26-09.pdf

Klann, G. (2003). Character study: Strengthening the heart of good leadership. Leadership in Action, 23, 3-7. doi:10.1002/lia.1020

Kuhlman, T., \& Farrington, J. (2010). What is sustainability?. Sustainability, 2(11), 3436-3448. doi: $10.3390 / \mathrm{su} 2113436$

Lovins, A. B., Lovins, L. H., \& Hawken, P. (2007). A road map for natural capitalism. Harvard Business Review, 85, 172-183. Retrieved from https://hbr.org/2007/07/a-road-map-fornatural-capitalism

McNally, C. A. (2013). How emerging forms of capitalism are changing the global economic order. AsiaPacific Issues, 107, 1-8. Retrieved from www.asia-studies.com/aps.html 
Miceli, M. (2015, September 17). Google tops reputation rankings for corporate responsibility. U.S News. Retrieved from https://www.usnews.com/news/articles/2015/09/17/google-topsreputation-rankings-for-corporate-responsibility

Moir, L. (2001). What do we mean by corporate social responsibility? Corporate Governance: The International Journal of Business in Society, 1, 16-22. doi:10.1108/EUM0000000005486

Narveson, J. (2014). Capitalism. Value Inquiry Book Series, 276, 47-49. Retrieved from www.brill.com/products/series/value-inquiry-book-series

Owie, E. T. (2017a). Leadership, followership, and dyadic role making: A review. Advances in Multidisciplinary \& Scientific Research Journal, 3, 21-24. Retrieved from http://www.isteams.net/aims-journal

Owie, E. T. (2017b). The future of management and associated social implications: A position paper. In O. B. Longe (Ed.), Proceedings of the 9th iSTEAMS Multidisciplinary Conference (pp. 197202). Legon, Ghana: University of Ghana. Retrieved from http://www.isteams.net/copy-ofisteams-home

Peterson, E. A., \& Patel, D. S. (2016). Benefit corporations: Fostering socially conscious corporate leadership. Southern Journal of Business and Ethics, 8, 92-108. Retrieved from http://www.salsb.org/sjbe/v8_SJBE_2016.pdf

Putrevu, S., McGuire, J., Siegel, D. S., \& Smith, D. M. (2012). Corporate social responsibility, irresponsibility, and corruption: Introduction to the special section. Journal of Business Research, 65, 1618-1621. doi:10.1016/j.jbusres.2011.10.020

Ramsey, J. L. (2015). On not defining sustainability. Journal of Agricultural and Environmental Ethics, 28, 1075-1087. doi:10.1007/s10806-015-9578-3

Reich, R. B. (1998). The new meaning of corporate social responsibility. California Management Review, 40, 8-17. doi:10.2307/41165930

Stibbe, A. (2013). The corporation as person and psychopath: Multimodal metaphor, rhetoric and resistance. CADADD Journal, 6, 114-136. Retrieved from http://cadaadjournal.com/\#

Strauss, K. (2016, September 15). The companies with the best CSR reputations in the world in 2016. Forbes Magazine. Retrieved from https://www.forbes.com/sites/karstenstrauss/2016/09/15/the-companies-with-the-best-csrreputations-in-the-world-in-2016/\#31a75d457506

Sundaram, A. K., \& Inkpen, A. C. (2004). The corporate objective revisited. Organization Science, 15, 350-363. doi:10.1287/orsc. 1040.0068

Valente, M. (2010). Demystifying the struggles of private sector paradigmatic change: Business as an agent in a complex adaptive system. Business Society, 49, 439-476. doi:10.1177/0007650310369376

Van Marrewijk, M. (2003). Concepts and definitions of CSR and corporate sustainability: Between agency and communion. Journal of Business Ethics, 44, 95-105. doi:10.1007/978-94-0074126-3_32

Waldman, D. A., \& Siegel, D. (2008). Defining the socially responsible leader. The Leadership Quarterly, 19, 117-131. doi:10.1016/j.leaqua.2007.12.008

Wexler, M. N. (2008). Conjectures on systemic psychopathy: Reframing the contemporary corporation. Society and Business Review, 3, 224-238. doi:10.1108/17465680810907305 
World Business Council for Sustainable Development. (1998). CSR: Meeting changing expectations. Retrieved from

http://www.wbcsd.org/pages/edocument/edocumentdetails.aspx?id=82\&nosearchcontextkey=t rue

Yammarino, F. (2013). Leadership: Past, present, and future. Journal of Leadership \& Organizational Studies, 20, 149-155. doi:10.1177/1548051812471559

The Journal of Social Change, sponsored by Walden University, welcomes manuscripts focusing on interdisciplinary research in social change that improves the human condition and moves people, groups, organizations, cultures, and society toward a more positive future.

Walden University Publishing: http://www.publishing.waldenu.edu 